\title{
Language, meaning, sense and reference: Matthew's passion narrative and Psalm 22
}

\author{
Sjef van Tilborg \\ Katholieke Universiteit Nijmegen
}

\begin{abstract}
Language, meaning, sense and reference:

Matthew's passion narrative and Psalm 22

The passion narrative of Jesus as told by Matthew is a verbal enunciation which finds its place next to other passion narratives in which the narrator lets the protagonist use the words of the 'I' person of Psalm 22 and in which the narrator describes internal and external conflicts with the words of the Psalm. Against the background of the Greek Septuagint and the Aramaic text in the Targum, parallel to what the hymnist of Qumran tries to do and the narrator of the story about Aseneth, based on the narrative as we find it in Mark, Matthew took Psalm 22 as anchor for his story. What is described in the Psalm, happens in the life and death of Jesus. To approach Jesus' passion more closely, Matthew used poetic language: words on words on words. The passion and death of Jesus has thus become literature, an ambiguous attempt to express the impossible. The question, 'how can one maintain today compassion against the forces of violence?', is the concern of the article.
\end{abstract}

Innocent sentences do not exist. Once a sentence is uttered it begins to lead a life of its own. It enters into communication with other sentences: either in support or in contradiction, or even without any connection, but still connected with other sentences as in a crazy quilt. Sentences receive meaning in various contexts, ever changing. The sentences themselves change thus in meaning. People express themselves in words and, in the meantime, these words start to lead a life of their own with their own and often obstinate relationships which their creators did not foresee but do occur anyway.

As I speak here and now in South Africa*, I realise that I act in a very

- Paper delivered 7 April 1988 at the HSRC Conference in Pretoria on Paradigms and Progress in Theology. 
special context. Obviously, I cannot see all the aspects of the South African context but I have prepared myself by studying the Kairos Document, the document edited by the Centre of Hermeneutics in Stellenbosch, The option for inclusive democracy; by reading W Mandela's Ein stük meiner Seele ging mit ihm, and the Festschrift presented by South African New Testament scholars to Professor Bruce Metzger. I see people and situations and I realise I can only think, read and interpret from my own situation in the Netherlands and my own problems. This speech is thus an intervention from another part of the world, literally fallen from the sky without knowing precisely where connections can be made and where not.

I speak from my own social situation where Thatcherism is in the ascendency: the privatisation of governmental concern in health, education and the media; the demolition of social security; the consolidation of the free market principle and the fragmentation of leftist organisations. There is a superabundance of initiatives which are lost in fragmentary activities.

Economic changes occur before our eyes. The unhappy results are easily visible for whoever wants to see them but, nevertheless, the changes are carried through: people who do not take care of themselves, will not survive. How can one maintain compassion against the forces of such violence? This question is really the whole concern of my argument. I cannot do less. I am aware that this is saying something. But it is necessary, if humanity is to survive. The right of the weakest against the right of the strongest, starting at the beginning again, because the social context has changed and all meaning has shifted.

I want to speak about the passion narrative of Matthew in communication with people who suffer from governmental violence. I am quite aware that I cannot do that in a direct way. Meanings cannot be connected on command. But I can show how, by recording his story about the suffering and death of Jesus in a text, the narrator of the Matthean passion narrative has left traces of meaning and what they are. I want to do this according to the scientific rules, so as to stay in touch with the forces which lie at the root of state-violence. I am given no other choice. I am part of the social context: to rationally show the irrationality of social violence, a conflict which will return time and again. 


\section{THE NARRATIVE AS AN ENONCEE}

\subsection{The right approach}

The time has come to discuss the story itself: the passion narrative as told to us by Matthew. After Jesus has been taken prisoner and has been interrogated, at the moment that he is, for the last time, 'handed over': after Jesus has been 'handed over' into the hands of the high priests and the elders of the people by Judas (26: $47 \mathrm{ff}$ ); after Jesus has been 'handed over' by these people into the hands of Pilate the governor (27: 2), Pilate now 'hands' Jesus over into the hands of the soldiers. And these soldiers of the governor accept him (27: 26-27). The story of the crucifixion can now begin.

In a way, it is really a very simple story. The facts are starkly told. From the point of view of the narrative there does not seem to be a problem: scene follows scene and one knows exactly, as a listener, what is what; a scene of mockery by soldiers, there is the story of the crucifixion with the comments of the by-standers and then the death scene with cosmic happening and at the end the testimony of the centurion and his troops. It is the kind of narrative the Germans so nicely call ein Bericht, with all its connotations: a report which records events happening in the past.

The problem begins, when one asks one self what the writer means to say by telling his narrative: a question which exegetes constantly ask themselves in response to their own and to other's reading. There must be more than the discursive sentence that Jesus died after he was crucified. Matthew could very well have said just that, but he did not. And every reader who has read his narrative, knows that Matthew has a lot more to say.

We need to concentrate on that 'more' but what is the right approcah? I can see three erroneous ways to approach the problem.

- It is not enough to limit oneself to often arbitrary meanings, if one wants to trace the real meaning of a text. Even less so when this presents itself in pronouncements such as: this means that: the tearing of the curtain of the Temple means the destruction of the Temple (Lamarche 1974: 582ff; De Jonge 1985: 349ff; 1986: 67ff); the splitting of the rocks and the opening of the tombs are eschatological happenings which symbolise the meaning of Jesus' death ('Matthew clothes the death of Jesus with a number of apocalyptic signs' - Meier 1979: 203; 'The raising of the saints and the confession of the Roman 
soldiers ... prefigure for Matthew his own church of Jewish and Gentile Christians' - Kingsbury 1975: 77). I am not saying that such explanations cannot clarify something, but they do not answer to the problem that all other happenings also claim an explanation. Unless one wants to reduce to simple facts the soldiers' mockery of Jesus, the blasphemous behaviour of the by-standers, the crucifixion of Jesus and his cry of anguish on the cross, or, to say it in other words, unless one accepts that these 'happenings' are just facts which refer to the past and which are now finished and done with, one has to take a decision on some 'meaning' of this part of the narrative. As in the same way but in reversed order one must accept that the eschatological happenings after Jesus' death are, for the narrator, as factual as all other things he told us about Jesus. The narrative of the crucifixion is, in its totality and its parts, a Bericht, the meaning of which may come to the fore in the process of reading or not. This may lead to the first conclusion: there is no preferred place of meaning in the narrative but, at the same time, the narrative tells us more than the simple fact that Jesus died after having been crucified.

- When we discuss the text of Matthew we must leave the text of Mark out of consideration for as long as possible. I know how tempting it is to use this parallel text in order to pinpoint Matthew's own point of view by comparing the similarities and differences. It is a possible way of reading the text following the results of Form-and Redaktionsgeschichte (Senior 1975). But this way of reading is, in the end, reductionist for Matthew's text. Even in the supposition that Matthew uses the words of another narrator, he still tells the narrative himself. Nowhere is there any evidence that he quotes. Therefore, he presents himself as the original narrator of the story. Even if this is not true, it remains his point of view. As listener one must try to respect that.

- I do not want to elaborate on this, since during the last few years this way of reading Matthew draws a good deal of interest and shows its first results (Frankemölle 1983; Kingsbury 1986; Kodjak 1986; Senior 1985). However, it implies a consequence which has not yet been accepted in the same way. It means that one must, for the same reason, accept not to look at references to other texts: especially to Psalm 22 or Psalm 68, to Wisdom 2 or Ezekiel 37 (for this last reference, see Senior 1975: 319ff).

I am not saying that this intertextual reality is without significance for 
the meaning of Matthew. I will come back to it extensively, but in the first instance I say that it is necessary to distinguish between text and intertext. Matthew's narrative does not quote from other texts. This is true even for the words which Jesus cries aloud '... my God, my God, why have you forsaken me'. Jesus himself speaks these words. He is not quoting a text in the literary theoretical sence of the word, even though he cries out the words of a sentence from Psalm 22. Jesus is, here also, the original speaker of this sentence. In the second instance, for later listeners and readers, he uses words from Psalm 22 and Matthew tells his narrative using words from Psalm 22, but in itself this is not true for the story itself.

\subsection{The point of view of the narrative}

Matthew's text is the central point together with the reality which this text brings to life: the destruction of Jesus by the soldiers of the Roman occupying force and the reactions of those who participated in Jesus' life: those who are the immediate executors of this institutional violence, those who pass by, those who are his adversaries and those who are sympathetic close by or from afar. The narrator Matthew creates in his story a specific reality which asks the listeners to give meaning to it.

It is first of all important to see that this narrative expresses a point of view which, at least to this extent, is unique in Matthew. This is a story of mockery, humiliation and total lack of understanding; yet, notwithstanding all this, Jesus' dignity remains - a narrative on two levels. No reader can remain ignorant thereof and yet it creates ambiguity.

A misunderstanding has been avoided because the narrator constantly explicates the attitude of the various participants:

27: 31- when the soldiers had finished their mockery ...

27: 39 - the passers-by hurled abuse at him: wagging their heads and saying...

27: 41- so too the high priests with the scribes and elders mocked him...

27: 44- even the bandits who were crucified with him taunted him in the same way.

When the narrator stops adding these qualifications, as with the man who offers him vinegar (27: 48) or with the people who say: 'Stop that, 
let us see if Elijah will come and save him' (27: 49), the listener is not certain any more how to interpret this behaviour: is this meant well? is it an innocent misunderstanding? or is it evil-minded? Judging from the previous part of the narrative this last interpretation seems the most likely, but one cannot be absolutely certain*.

Whichever way one reads it, the narrative of the crucifixion is, in the eyes of the majority of the readers, an inverted narrative of exaltation. From this perspective it runs parallel to other narratives in Matthew which relate the exaltation of Jesus: the narrative of the temptation in the desert (Mt 4); the narrative of his walking on water and Peter's testimony (Mt 14: 22ff); the narrative of the transfiguration on the mountain together with Moses and Elijah (Mt 17); the narrative of the entrance in Jerusalem (Mt 21); the narrative of the interrogation before the Sanhedrin (Mt 26: 57ff), the narrative of the resurrection and the final mission given to the disciples on the mountain in Galilee (Mt 28). One single inverted narrative and so many direct exaltations. Are we capable, as readers, to take the text seriously and is there no danger that the narrative disappears under the verbal violence of so many positive aspects?

\subsection{The colour of the narrative}

The narrative begins like a feast of soldiers. The interrogation is finished and Pilate took the alternative of the least resistance. He did not even listen to the prophetical dream of his wife. He washed his hands, although not in innocence, and the people have taken all blame upon themselves but they are misguided. Jesus is handed over to the soldiers who will fulfil their duty.

Soldiers are a symbol of violence and destruction, of the dark forces in life which are called forth on that borderline between life and death, where light turns to darkness, where the twilight evokes spirits which are not to be controlled. The crucifixion-narrative is usually read in a very straightforward fashion, as a story where events happen in the clear light of facts. Yet there are a number of aspects belonging to the

- This is even more valid if Kingsbury (1975: 74) is right in his literary division in which the threefold rejection of Jesus in $\mathrm{Mt} 27: 39,41,44$ is put in parallel to the threefold attestation of Jesus as 'son of God' in Mt 27: 47, 51, 54. He does make a judgement on Mt 27: 47 (Jesus who addresses his father and thus promotes himself to the position of son) but he wisely keeps silent about Mt 27: 48-50. 
telling of the narrative which indicate that there is something more to it. Before going into the discursive aspects of the narrative I want to say something about those narrative realities.

Let me put the data together:

Mt 27: $27 \mathrm{ff}-{ }^{\prime} .$. the soldiers enter the pretorium and call the whole cohort of Jerusalem together to have their fun with Jesus': There are a number of blank spots in this story, but it is clear that the soldiers act not-in-public but on their own grounds and on their own authority (cf 27: 32 - 'coming out in the open'). It is clear also that all of them are present - 'the whole cohort', a small army of some 720-1000 men (cf Josephus, Bell Jud 3: 67). Militarily spoken this is not a feat, but the narrator has heard the lugubrious fun they have had with Jesus (27: 31).

Mt 27: $33-$ '... arriving at a place called Golgotha (which means "place of a skull")': This is not just a material place indication. As translation of Golgotha and as indicative of the crucifixion scene, kránion must be seen as an indication of death in its most negative form. A popular etymology via gulgolet, gulgalta is: head, tax per head, skull, death-head (cf Abot 2: 8).

Mt 27: $40-$ - ... if you are a son God': Exegetes always point out that the wording of this expression of ridicule refers to the narrative of the temptation where 'the tempter', 'the devil', 'satan' says twice 'if you are a son of God' (Mt 4: 3, 6). In other words, the passers-by in the crucifixion scene speak a satanic language. This is even intensified by the fact that they challenge Jesus to perform a miracle, the way the devil does. By asking Jesus to rebuild the Temple in three days they reveal their inner thoughts. Matthew knows that the words the mouth utters, come from the overflowing of the heart (12:34).

Mt 27: $42-$ '... he saved others but he cannot save himself': This expression fits in with the above-mentioned 'demon'-context. It comes from the criticism of prophets: a prophet who cannot help himself, proves to be a false prophet, that is someone who is not led by the divine pnêिma (cf for example Lucianus, Alexander, 59; Apuleius, Metamorphoses, II, 12,3-14,6). The accusation does not really affect Jesus - he prophesied his own death - but it hits back at the accusers themselves (cf Mt 12: 22ff).

Mt 27: 45- '... a darkness over the whole land, for three hours': Night comes in the middle of the day.

Mt 27: $50-' .$. with a great cry he gave the spirit' (afièmi as 'sending away', 'giving up', 'letting go'). Many people seem to imagine this to mean that the pnêuma of Jesus then disappears from Golgotha. I am not 
so sure any more. According to Jewish thought, the pneûma of a dead person remains close to the body for three days. We all know that when we read John 11: 39 where Martha tells Jesus 'he is already four days in the tomb' (cf Str -B on this verse). That way of thinking will also be true for this narrative.

Mt 27: $51-{ }^{\prime} \ldots$ the tearing of the Temple veil, the earthquake, rocks which split open, tombs which are opened, the bodies of the saints which rise up': it is a list of terrifying happenings which do not cause Golgotha a pleasant place to be - the netherworld opens with much noise and violence. The place of the skull is a rocky cemetery where many are buried who now come to life again.

Mt 27: $53-{ }^{\prime} . .$. and coming out of their graves after his resurrection they entered the holy city': The usual supposition seems to be that the bodies of the saints come to life after Jesus' resurrection. The translation will then be: '.. after his resurrection they came out of the graves and entered the holy city'. Anything else would not do justice to the right of Jesus as the first born from the dead*. I find the other presentation more reasonable: '. . and they came out of their graves and after his resurrection they entered the holy city'. The risen but invisible bodies are palpably present near the body, the somma of Jesus on his cross. Anyway, the centurion and the soldiers are overcome by a numinous fear.

Soldiers, demons who speak through the mouths of people, a place in the form of a skull, darkness in the middle of the day, a spirit that stirs the netherworld, bodies of saints who rise from their tombs and hold a wake, soldiers again who seem to become believers: Matthew's crucifixion narrative has the dark colour of the night of death.

\subsection{The discourse in the text}

If communication with a text comes into being, then it certainly does so via the sentences which the people in the story exchange with each other. The direct speech in a text has pride of place in the communication between a narrator and his narratees. There is an order of importance. What a main character says, is more important than what

* Cf Senior (1975: 316) where he writes on the differences in interpretations: 'The different translations are) not of capital importance for the interpretation', and who nevertheless, writes on page 322: 'Matthew hastens to reaffirm the priority of Jesus' resurrection that was, of course, a capital point of tradition.' 
we hear from second ranking characters. Spoken words have always precedence above narrated facts.

This is certainly true for the passion narrative in Matthew. The exegesis of our passage demonstrates that. The sentences spoken by the characters in this story define the meaning of the text. As I said above, they do this indirectly - through ridicule and slander - but that does not diminish its importance. The passion narrative is a christological narrative. It receives this imprint because everyone speaks about Jesus: the soldiers who address him as 'king of the Jews' (27:29) and who affix these words to the cross $(27: 37)$; the passers-by and the leaders of the people who call him 'son of God' (27: 40-43) and 'king of Israel' (27: 42); the centurion and his soldiers who also see in Jesus a 'son of God' (27: 54). The passion narrative is a narrative about the names of Jesus and about his relationships with God and with Israel.

However, it does not end as positively as one usually presents it. Initially it does not look all that bad. One pronoucement follows another. If we place them one after the other, an even closer relation with the main character appears:

Mt 27: $37-' \ldots$ this is Jesus, the king of the Jews': third person as objective description;

Mt 27: $41-$ '... if you are a son of God': second person in an address;

Mt 27: $43-'$... he has said: I am a son of God': first person in a quote from Jesus himself.

But when, after all these commentary-sentences, Jesus finally speaks for himself, all self awareness is gone. We are so used to this word on the cross that we possibly forget that something quite extraordinary is happening. It is the first and only time in Matthew that Jesus speaks not in Greek but in Aramaic* (see esp Burchard 1983: 8): a shock for the listeners who get the message that Jesus is a bárbaros, the last words of their hero in a language which is not understandable. The reaction of the listeners under the cross makes clear how alienating this must have been. They try to give it some meaning: that 'that man' calls for Elijah

- This is different from Mark where Jesus spoke non-Greek three times before this (5: 41; 7: 11,34) - texts which look different in Matthew (cf esp Burchard 1983: 8). For the rest, Matthew uses some Hebrew words which must have been quite unknown to his Greek readers. In diminishing importance we find raká, Korbân, hösanná and rabbi. 
and that they would like to see whether Elijah will come to help him. For the listeners to the story, the narratees of the narrative, this reaction is strange because through the translation they know what Jesus has said but this is probably not true for the characters in the story itself. Their reaction seems to be rather a demonstration of the absolute aloneness of Jesus. He cannot communicate with anyone.

This becomes even more intense when we take to heart the content of this word of Jesus. Jesus, this son of God, has lost his father. However much this outcry expresses also the depth of his desire for God, every listener has understood and does understand that the source of his life has become invisible for Jesus in the darkness of the day: a son of God without God. The story pulls the rug from under its story really. God who carries the meaning of the narrative is indicated as absent by the main character of the narrative.

This undisputable zenith of the narrative is not withdrawn, not in the events after Jesus' death as I believe I have proved, but also not in the testimony of the centurion and his soldiers: 'Truly this man was a son of God' (27: 54). This might have been different if it said: '. . truly this is a son of God'. The past tense used in the testimony points to a reality which existed before the death of Jesus and which is not present anymore. In fact it is now the last attestation of Jesus' death and it does not offer any perspective for a life after death. The presence-withoutany-comment of the many women who came with Jesus from Galilee, at the borderline of the narrative, at the transition from death to new life, is in a certain sense more symptomatic for the meaning of the story itself. Eye to eye with so much senseless suffering one can only be silent.

\subsection{The story as told}

It will be clear which way I am going in the analysis of this text. It becomes progressively more difficult to maintain the communication with the text. The closer one is to facts, the more dense the meaning becomes. We still need to treat the meaning of the events as told, the simple facts which are true simply because they are factual: Jesus is dressed as a king by the soldiers and is later stripped by them; Simon from Cyrene is forced to carry Jesus' cross; Jesus is stripped and his clothes are divided among the soldiers; two robbers are crucified with Jesus; Jesus dies on the cross; the curtain of the Temple is torn from top to bottom; the netherworld is opened. 
Anyway, the narrative tells how Jesus is reduced to being a body, a soma. Once he is in the hands of the soldiers, Jesus is just a willing plaything, or rather, the soldiers make him a plaything. It is striking how often there is mention of Jesus being dressed and stripped. The whole cohort is present when he is undressed, dressed, undressed again and dressed again (27: 28,31). Arriving at Golgotha he is stripped again and the soldiers take possession of his clothes. He hangs on the cross naked and nothing is visible until Joseph from Arimathea gets Pilate's permission to take down the sōma of Jesus and wrap it in a clean cloth (27: 59).

Even before Jesus died he was made into a sōma: Golgotha, gulgalta per head of the population, per head for tax imposition, skull. Simon from Cyrene suffers the same fate. His being 'forced' as the text spells it out (27: 32), is a technical word for enforceable liege services: the possibility for the powerful and the state to force anyone to give service. In Matthew it refers back to the Sermon on the Mount, to the interpretation of the law on 'an eye for an eye, a tooth for a tooth' by Jesus: 'I tell you not to resist the evil one, but if someone slaps you on the right cheek, turn off and offer him your left. And if someone wants to sue you for your shirt, let him have your coat as well. If someone forces you to go one mile, go two with him' (5: 38ff). Soldiers do not see persons. They look at people as sommata (the classical expression for slaves). They see them in as far as they can be used. They look at the balance of power and interpret in their own fashion how a command is to be executed: hitting and spitting when they are with their comrades; giving wine and vinegar because that is prescribed in the rules - Jesus refuses to take it, probably because the narrator wants to say it openly that Jesus was undergoing his passion consciously - performing the given task: to nail Jesus to the cross; to put up the titlos; to guard - but seated because it may be a long wait.

I indicated above how this destruction of Jesus to a dead body calls forth spirits which the soldiers cannot control: people who speak a demonic language, the spirit of Jesus who remains close to the body, the invisible bodies of the saints who died - Golgotha as a horrendum. The real empty space is that God himself is visibly absent (or can we use a double denial here: God invisibly present?). Notwithstanding calumny, ridicule and abuse, God does not act. He leaves Jesus hanging on the cross, even when Jesus calls his God by name: 'Eli, Eli ...' God's 
interference is presented only anonymously: in the use of the passive form where it is mentioned that the rocks are split, the curtain is torn, the earthquake, the opening of the tombs - an active God who shows himself in passive reality, actio in passione, praxis in pathos. The trigger is the tearing of the curtain of the Temple. This has called forth a lot of creative reader's activity which I shall not discuss here. As a 'fact' it simply indicates that the holy of the holies in the Temple has become visible for all present. The shekinah of God is visibly absent just as the naked Jesus shows only his body*. The crucifixion narrative wants to express the impossible. In sentences which carry meaning, the senseless wants to be said. It is not really surprising that 'own' words are missing.

\section{THE NARRATIVE AS ENUNCIATION}

The last word has not been said yet. The passion narrative of Matthew as enunciation is determined by an extensive intertextuality. In a certain sense it stands literally in line with Mark's narrative. It is part of Matthew's gospel as part of a whole. Indirectly it refers to biblical texts: Psalm 22, Psalm 68, Wisdom 2, Ezekiel 37. It is not an independent text, standing by itself, but there is a relation with a multitude of other narrative expressions which influence its meaning and function. I want to limit myself here to study the relations between Matthew's text and Psalm 22. This is only one aspect of the intertextual ensemble, be it a very important one.

\subsection{Psalm 22 in Matthew's text}

What we need here is linguistic precision: little indications have their place next to clear references. Intertextuality is a nuanced reality with quotes and allusions, but also with more subtle textual phenomena**. In

* With this interpretation I follow the interpretation of Melito of Sardes, In Pascha 98: 101-102: the tearing of the curtain of the Temple as the 'tearing of a dress'; vs 53-54 as referring to a 'descent into Hades' - to my mind it is rather an 'ascent of Hades' (cf De Jonge 1986: 75 ; and also T Levi 10: 3 -'... so that he [the Lord - S v T] will not bear Jerusalem because of your wickedness, but will rend the covering of the Temple so as not to cover your shame').

* See Köhler (1987) who developed criteria to determine the (possible) reception of the Gospel of Matthew. He makes a number of distinctions:

- eine Aufnahme die als solche gekennzeichnet ist (Zitat als Specialfall);

- eine Aufnahme die nicht als solche gekennzeichnet ist (Anspielung als Specialfall); 
accordance with this distinction I divide the data in three categories: the quasi-quote; the allusions; the references.

\subsubsection{The quasi-quote}

Mt 27: 46 - 'Jesus' crying out loudly': This is not a quote in the literary-technical sense of the word, because the text does not qualify it as such. But it is very close to it, because there is a verbal similarity with Psalm 22. However, I must make some reservation. The Aramaic as well as the Greek text in Matthew show similarities but also discrepancies (Gundry 1967: 63ff) between the Targum and the Septuagint. And the Greek translation by Matthew is more in accord with the Aramaic sentence spoken by Jesus than it is with the Septuagint. Gundry's thesis, therefore, '... that Matthew was his own targumist' (Gundry 1967: 172) seems to be in line with these linguistic data.

Apart from this formal confirmity I can point also to a conformity in enunciation. Because of the use of the address, 'My God, my God', and because of the singular in 'you' and 'me', the text from Psalm 22 should be seen as a text spoken by someone who prays. And it is exactly this what Jesus is doing by crying out the opening verse of this Psalm. Since he identifies himself with the implied speaker of the text, he makes these words his own.

\subsubsection{The allusions}

Mt 27: 35 - '... they divided his clothes by casting lots': This is a clear allusion to Psalm 22: 19: '. . . they share out my garments among them and cast lots for my clothes' (cf Gundry 1967: 62). The disticha must be seen as parallel sentences where the 'sharing' of the preface is concretised in 'casting lots' in the next sentence. In Matthew's text this is brought together in one sentence. The anonymous adversaries of Psalm 22 are now identified as Pilate's soldiers, because the sentence is now part of the passion narrative.

Mt 27: 39-44-A cluster of allusions on Psalm 22: 7-9 determines the intertextual reality (cf Gundry 1967: 62f, 145): 'the wagging of heads' of the passers-by (Ps 22: 8); 'the abuse' of the criminals (Ps 22: 7); the

- die Aufnahme von Formulierungen und von Inhalten Gedanken;

- inhaltlich zustimmende Aufnahme und inhaltlich weiterfürende Annahme;

- inhaltlich ablehnende Aufnahme.

Intertextuality is an even more important linguistic reality than the reception of a text. 
'scorn' of the high priests (Ps 22: 7-8) who say, 'He threw himself on the Lord for rescue, let he deliver him, if he holds him dear' (cf Ps 22: 9).

The unidentified people of Psalm 22 ('the people', 'persons', 'all who see $\mathrm{me}^{\prime}$ ) are again identified in Matthew as 'the passers-by', 'the high priests and pharisees and elders', 'the criminals who were crucrified with him'. Scorn is shared among the various groups and thus becomes more massive. The humiliation is also worse because of this particularisation:

- (chance) passers-by make a stand against Jesus;

- the words of scorn are spoken by high priests, pharisees and elders of the people, that is precisely the people who have a special affinity to religion because of their function;

- the criminals who are crucified together with Jesus abuse him, that is those people who break the Law against the one who is faithful; they are in the same straight but yet they turn against him.

\subsubsection{The references}

These factual inferences of Matthew's text and Psalm 22 open the way for us to look at both texts with even more precision. If we take Psalm 22 as point of departure we see other points of contact; even more if we accept the Septuagint and the Targum as arche-texts. There is some danger of getting into a vicious circle because of the lack of precise information about the date for these texts. Therefore, we should not think in terms of dependency but rather see them as parallels models. With this reservation in mind I want to emphasise the following:

- Mt 27: 33 (the skull space) and 27: 52 (the tombs with the bodies) run parallel to Tg Ps 22: 16 where the Hebrew 'dust of death' is translated as 'the house of the tomb', that is '... you bring me to the burial place'.

- Mt 27: 36 ('... they sat down to keep watch') is a reference to Ps 22: $18 \mathrm{~b}$ ('... they look on and keep looking all the time'). It is a way to objectivize which also plays a role in the constant dressing and un-dressing of Jesus.

- Mt 27: 50 ('... he gives up his spirit') refers to Ps 22: 21 ('Deliver my soul from the sword, my life from the leg of a $\operatorname{dog}^{\prime}$ ). The Hebrew is translated in Tg Ps 22: 21 as '... save my soul from those who kill with the sword, from the leg of a dog save the spirit of my body'. The pneûma is the life-principle which must be saved. 
These three references (together with the certain allusion of Ps 22: 19) strengthen the application of Ps 22: 16-21 to the soldiers around Jesus, that is Matthew's text creates a link between 'the dogs', 'the evil ones' in the Psalm and the Romans (= non-Jews), a link which is generally accepted in Jewish though (cf Str - B I, 722; Abrahams 1967/2: II, 195).

- Mt 27: 40, 44 (Jesus as 'son of God') relates to Ps 22: 10 (11) ('... from the womb I have been entrusted to you, from the belly of my mother you were my God'). This 'belonging to God' is expressed even more strongly in both the Septuagint and the Targum. The Psalm verse links up with the opening sentence that God is the only refuge for the I prayer of the Psalm.

- Mt 27: 45 (the 'darkness' and 'daylight') makes Ps 22:3 real: 'My God, I call during the day and you hear me not; I call during the night but there is no rest for me'.

That means that the identification of Jesus and the man who prays in the Psalm (already realised in the quasi-quote) has other bases in the Psalm*.

The narrator in the Matthean text has extensively used Psalm 22. Probably this was handed to him in the tradition of the narrative, but the intermingling of the historical facts and the text of the Psalm continues here. We could say that Psalm 22 has had an even greater influence but not directly. There is the intermediary of the interpretation of the Psalm which is as a cloud between the Psalm and the Matthean text. The first part of the Psalm is looked at as a description of historical reality and no use is made of the positive closing section of the Psalm.

\footnotetext{
* Mt 27: 52, 53 ('... the raising of the bodies of the saints from the tomb') could be a reference to Ps 22: 30 ('All those who have gone down to the dust shall bow before his face'). This reference is sometimes seen as rather important (see e g Gese 1961: 17) because the positive conclusion of the Psalm would then be part and parcel of Matthew's narrative. I am not so convinced. In any case, I want to point out the differences between the general pronouncement in the Psalm where all the dead give honour to God, and Matthew's text where only the bodies of the saints rise. Matthew's text suggests a post-mortal distinction between good and evil, a distinction which is important for Matthew, considering Mt 13: 30, 41f, 49f; 18: 9, 34f; 22: 13f; 25: 12, 29f, 46 . Therefore, a direct reference to Ps 22: 30 is practically impossible.
} 


\subsection{Psalm 22 in Jewish literature}

Such interpretation and function of a Psalm in New Testamentary exegesis is not something unique. The gospels are not the only writings which have used the Psalm in this way. Psalm 22 is also seen as historical in other Jewish literature. I will indicate this in more detail.

\subsubsection{The Septuagint translation}

Le met start at the beginning, with the interpretation which is probably the first in time: the Septuagint translation of the Psalms. One does not usually read this translation as an interpretation. Usually the text is used, parallel to the Masoretic text, to indicate difficult linguistic problems and/or to solve them, that is puzzles in the Hebrew text for which an alternative is given in the Septuagint. The generally accepted supposition is that the Septuagint translator(s) had access to an earlier and slightly different Hebrew text which can be reconstructed from the Greek. This certainly plays a role in Ps 22: 17, 22 where inexplicable Hebrew lexemes are translated in an intelligible way (cf Ps 22: 7 - '... they have pierced' for k'ry; Ps 21: 22 - 'my humiliation' for 'nytny). But this does not solve all problems because sometimes the Greek is as unintelligible as the Hebrew*. The access to these texts and their meaning was also apparently inaccessible to these translator(s).

To translate is also to interpret. This is true also for the Septuagint translation of Psalm 22. Additions and choices in translation show the ' $I$ ' person in a slightly different relation to God than the Masoretic text. There is a hint of a guilt feeling** and the situation of dependency is more pronounced ${ }^{* * *}$. The wellbeing of the praying person is more directly connected with God in the very core of his being. Only God can help him and can offer him a chance for survival through his soul and his seed: '. . my soul lives from him and my seed will serve him' (vs 21: $30 c, 31)$. God, saviour, is faithful to him who prays. Especially important

* Cf Ps 21: 21 where yhydty is translated into tèn monogené mou. The same thing happens again in Ps 34: 17. Likewise, the translation 'the eating of the fat ones' in Ps 21: 20 cannot structurally be inserted into the train of thought of the Psalm. Modern interpretations read the Hebrew ' $k l w$ as $a k$ lo ('for him alone').

* Through the translation of vs $2 b$; 'afar from my rescue, the words of my transgressions'.

*** Cf the addition, 'turn to me' in vs 2 , and the repetition of this is vs $20 \mathrm{~b}$; the translation of vs 10b; 'you are my hope from the breasts of my mother', and of vs $20 \mathrm{a}$, 'but you, Lord, do not postpone to help me'. 
is the deeper identification of the viccisitudes of this ' $\mathrm{l}$ ' prayer and those of Israel. Because the vocabulary has been shrunk in this Septuagint-translation if we compare it to the Hebrew text, the viccisitudes of the fathers and those of the ' $\mathrm{I}$ ' prayer are more similar. The lexemes 'to hope, to shout, to liberate, to save' are used to describe the liberation of the fathers in verses 5 and 6, while in the rest of the Psalm they are used to describe what happens to the ' $I$ ' prayer of the Psalm. And these acts of liberation must be an object of praise for the whole of Israel $^{*}$. The ' $\mathrm{I}$ ' prayer in the Psalm represents Israel. Israel's history is resumed in him and his salvation signifies an object of praise for the whole of Israel.

\subsubsection{The Targum}

The interpretative aspect is even more obvious in the Aramaic Targum. One can hardly call it a translation. There are so many replacements, additions and explanations in so many places that it is more a midrash than a translation. It has become a different text which presupposes its own context, even though very fascinating. The ' $I$ ' person who prays has become even more than in the Septuagint the representative of persecuted Israel. The hostile opponents are identified as idolators of stars' (Tg Ps 22: 13), as 'persons who are strong and big' (Tg Ps 22: 22), but God is on the side of Israel**.

The ' $I$ ' prayer calls himself a 'weak' worm despised by 'people' (in the plural!) and rejected by the peoples (also plural) (Tg Ps 22: 7). That is Israel living among the peoples and persecuted and rejected by the pagans (cf the addition in 22: 18 - 'they despise me'). The threat is against its life, but the rucha of the body will be preserved with God $(\mathrm{Tg}$ Ps 22: 21$)^{* * *}$.

- Cf the ryme which we now have between vs 4 ('Israel's praises') and vs 26 ('my praise in a large gathering') and especially the use of the subjunctive in vs 24 ('you who fear the Lord, you must/may praise him; the seed of Jacob, you must/may honour him; all the seed of Israel, they will fear him').

** See the applications in 22: 13 (' I am surrounded by those who adore the stars who can be compared to many bulls'); 22 : 17 ('I am surrounded by many evildoers who can be compared to many dogs'); 22: 17 ('I am surrounded by a gathering of mockers who as a lion wound my hands and feet'); 22: 22 ('free me from people who are large and strong as bulls').

*** See 22: 28 ('save the rucha of my body from the leg of the dog; and in contradistinction to this 22: 30 ('the soul of the evildoer will not live'), where the Hebrew 10 is understood as 'not'. To remain consistent 'the soul' must then be qualified. Modem interpretations follow the Septuagint and understand the Hebrew $l 0$ as $I w$ ('for him I= God]'). 
God does not abandon Israel. His word ( $\mathrm{Tg}$ Ps 22: 5) and name (Tg Ps 22: 23) are forcefully present ( $\mathrm{Tg} P s \mathrm{22:} 31$ ). He lives in the midst of his poor and his shekinah will not go away from them. (see the addition in 22: 25 - 'his presence does not rise from their midst'). They face a great future: their hearts will long for the spirit of prophecy ( $\operatorname{Tg} P s ~ 22: 27)$ and the future generation of Abraham will show the wondrous deeds of God to everyone*. Not a simple promise: the future of the world depends on it because the holy God has founded the world on Israel's praises.

God and persecuted Israel are identified in the viccisitudes of the ' $\mathrm{I}$ ' prayer. He is the prototype of Israel's persecution by the pagans, prototype also of its salvation which will come from God. Even if such

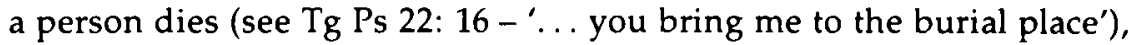
God is not absent, certainly not when the end is positive and we see an unexpected salvation. Israel's future does not depend on evil people. It is bound up with God's word which preserves its strenght notwithstanding all position and adversity. The future will show this.

\subsubsection{Allusions of the Psalm in the Septuagint (Wisd 2: 18 and 3 Macc 6: 11)}

Translations are bound to the whole text. They have to take position in relation to all the realities of a text. Quotes and allusions in other texts are obviously selective. The new writer selects from the archè-text without the need to give account for his selection. He puts it together in a new text and it is this new context which determines the specific interpretation.

There are at least two places in the Septuagint where there is a reason to believe that Psalm 21 (22) plays a role as archè-text. Both deal with the addressing sentences in the Psalm (vs 9) where the mockers are shown as addressing the ' $\mathrm{I}$ ' speaker: '... he trusted in the Lord. Let him deliver him. Let he deliver him because he loved him' (cf Sept 21: 9). This is a typical pronouncement, since the expression occurs only in Psalm 21 (22) and, when it occurs in other, later texts it can, therefore, be seen as a reference to this Psalm. The text stands on the side of the persecutors and lets them speak the typical mocking sentence.

In the literature we usually find mention only of Wisd 2: 18 , a text

\footnotetext{
* See the additions in 22: 31 - the seed 'of Abraham' which 'will show the forceful strength of Adonai' to the 'coming generation'.
} 
which is also in the background of Mt 27: 43 (Senior 1975: 287ff). The adversaries are the 'godless' (Wisd 1: 16) within Judaism (Wisd 2: 12) who react against the just one(s). They are prepared to put it to the test. They decide to test the just man, to torture him, even to put him to death, to see whether God will take his side. The just man believes himself to be a son of God. Let God rescue him then from the hands of his enemies (Wisd 2: 18). The allusions to Psalm 21 (22) are clear: the threat of torture and death, the relation of son-father in the just man to God, the mocking language which points, from a position of power, to the invisibility of this relationship: and what is invisible does not exist.

The author of Wisdom obviously disagrees with this as is clear from the rest of Chapter 3. For our context - the meaning and function of the Psalm - it is of great importance that the dispute between the godless and the just is seen as an intra-Jewish dispute. Israel itself is divided because of God's invisibility. Israel's history, the marvel of the creation and the admirable live of the wise man show something else, but the godless are caught in their own stupidity. The allusion to Ps 21: 9 in Wisd 2: 18 strengthens the readers' awareness that the godless are wrong. They are at the wrong side of truth and one should not follow their reasoning nor their example.

From 3 Macc 6: 18 we can see how the same text can function in a totally different context. The Jews in Egypt have been taken prisoner by the king and are packed into the hippodrome of Alexandria. They will be trampled by drunken elephants. They have been rescued a couple of times already: the king fell asleep once and another time he did not remember what he had decreed because he was drunk. But now the last moment for the Jews has come. The elephants are on their way to the packed hippodrome. At that moment the old priest Eleazar (= God helps) silences the others. He begins a long prayer in which he reminds God of the old history with Pharao, of Sennacherib, of the three comrades in the fire, of Daniel in the lion's den and of Jonah in the whale. 'Let not those who think vain thoughts bless their vain gods for the destruction of your beloved people and say, "Not even their God could rescue them"' (6: 18). The mortal enemies are the pagans, a king who will not give respect to the Temple in Jerusalem and Egyptians who encourage the king in his godlessness. The God of Israel stands against the gods of the Egyptians and by saving his people God can show who is the mightiest. The words of Psalm 21 (22) should encourage people in the face of death. For the readers of this narrative 
they are an announcement of the good ending of the story. Israel's God will not leave his people.

\subsubsection{The use of Psalm 22 in Qumran (1 QH 5)}

The famous Psalms of thanksgiving of Qumran are yet another Fundgrube for the use of Psalm 22. These are hymns fitted in biblical language and so it is natural that the language and imagery of the Psalms have had an influence. Anyhow, Psalm 22 plays a role here. It happens quite implicitly in the descriptions of fear and of terror: the heart of the ' $\mathrm{I}$ ' person melts like wax $(1 \mathrm{QH} 4: 33 ; 8: 32)$ or runs away like water $(2: 28 ; 4: 33 ; 8: 32)$; his bones fall apart $(7: 4)^{*}$; even more clear in the sentences which speak about the ' $\mathrm{I}$ ' person as someone who has been 'mocked and ridiculed' (2: 9; cf Ps 22: 7) (in 1 QH 2, however, it is God himself who ridicules the ' $I$ ' person of the Psalm); and even more expressly in $1 \mathrm{QH} 9: 29,35,36$ - the ' $\mathrm{I}$ ' person is entrusted to God from his birth, God has been favourable to him from his father and mother, from the womb, from the breasts of his mother (cf Ps 22: 10, 11)**.

All these allusions presuppose an explicit knowledge of Psalm 22. This supposition becomes a certainty when one reads $1 \mathrm{QH} \mathrm{5}$, a Psalm which from beginning to end refers to Psalm 22. This is done in a quite extraordinary manner: it is almost a mirror lecture. What is said in a negative way in Psalm 22, is found positively in $1 \mathrm{QH} 5$ : you did not leave me (5: 5 as opposed to Ps 22: 2); you closed the mouth of the lion (5: 9); they did not open their mouth (5: 11 as opposed to Ps 22: 14); in the anguish of my soul you did not desert me and you heard my crying (5: 12 as opposed to Ps 22: 25); you did not despise the little one (5: 20 as opposed to Ps 22: 25). The soul of the poor man will be saved (5: 13, $18)$, even though it is threatened by lions whose tongue is like a sword $(5: 13,18)$.

The impact on the interpretation of Psalm 22 within this hymn comes especially from the fact that there is a double persecution. In the first

- One might think that such imagery is quite common in the Old Tesament but that is not so. The expression that a heart melts like wax, appears only in Ps 22: 15; 2 Sam 17: 10 , does speak about a heart which melts but without the mentioning of the wax (see also Thorion 1983: 197ff).

** I believe that it is this thought which makes the 'I' person speak about himself as 'an orphan' (cf 1 QH 5: 20). The proposal by Domkowsky Hopkins (1981: 363) to see 'orphan', 'poor', 'miserable' etc as applicable to the persons outside the group, to the 'potentiality saved ones' as opposed to the 'actually saved members of the group', does not seem to be all that happy to me. 
part there is the exposure to the 'godless among the peoples' (5: 17) and in the second part there is the campaign of slander out of jealousy and anger by 'friends' (5: 22ff). The second persecution is worse and creates a deeper sense of pain. The use of Psalm 22 is less, in favour of Psalm 41; but not such that there would be no more references (cf esp 5: 31 '... my tongue cleaves to the roof of my mouth').

Psalm 22 had words for all manner of persecution no matter whether it is from without or from within as initiated by the group itself. The pain which is created by people is not very creative. It is monotonous in the way it is expressed.

\subsubsection{Joseph and Aseneth}

I want to finish this discusion with a last text, that is the love story of Aseneth and Joseph which is also a story of conversion of a pagan girl to Judaism. Aseneth, the rich and beautiful daughter of Pentephres, is touched by the divine emanation of Joseph when she sees him. In order to be able to marry him she destroys all the images of the gods, fasts for seven days and receives the message from an angel of the Lord that she is pure to eat the bread from heaven.

At the end of her week of penance she speaks to herself and to God, in lamentations*, which use Psalm 22 as reference obviously together with other references. We have the wild and old lion, the father of the Egyptian gods, who persecutes her and threatens her; she must be liberated from his mouth (Jos As 12: 9, 10); we have the description of the result of her weeklong fast: her mouth is dry, her lips are like a shard and her strength has left her (Jos As 13: 8)**.

From her own words we know that Aseneth realises that she is in the situation of the 'I' speaker in the Psalm. She calls on the God of Israel as the only one who can 'save' her. He is her 'hope', her 'father', her 'helper' (Jos As 12: 11 and of Ps 21: 10, 12; cf also the reference to the 'liberation from the danger of the sword' in Jos As 27: 7-11 and Ps 21: 21,30 ). She takes refuge with him; she calls to him in 'a loud voice' to

* In the modern discussion about this book it has not yet been cleared up which text should been seen as 'original' (see Burchard 1965 and Philenenko 1968 who resp defend the longer and the shorter version). The difference between the longer and the shorter version is not relevant for my thesis because the same reference can be found in both versions.

** The metaphor, 'her mouth is dry as a drum and her tongue as a horn' are typical; the phrase 'her strength gives out' can only be found in the longer version. 
be liberated from 'the people who persecute her'; she flees to this father as a child comes to father and mother (Jos As 12: 4, 7 and of Ps 21: 3, 10, $11,20,25)$. She presents herself as an orphan in distress, as someone who is deserted by all and hated by everyone - a loneliness which converts experience when they come to Judaism from a ruling main religion.

The words of Ps 21 (22) express again a passion history. The feeling for reality is not all that strong, at least for modern readers, because everything is enlarged in this narrative. Yet, real experiences lie in the background: a daughter of a priest at the court of Pharao who dares to take the courageous step of converting to Judaism is a model for the suffering which can come to any Jew who lives in a pagan environment. It should not be a surprise that the story of Esther plays such an important role in this love story.

\subsection{Physical suffering as verbal enuniciation}

I think we can now leave the deviation via the parallel texts* and return to the main theme: the passion narrative of Jesus as told by Matthew in the words of Psalm 22. It is a verbal enunciation which finds its place next to parallel ways of expression, next to other passion narratives in which the narrator lets his principal actor use the words of the ' $\mathrm{I}$ ' person of the Psalm and in which the narrator describes internal and external conflicts with the words of Psalm 22. Psalm 22 had its devoted readers and has been used several times to actualize events, although not all that often. So we cannot say that it is a commonplace or a genre. But repetition excludes also uniqueness or originality. In the mouth of the narrator(s) Jesus' passion and death does not escape the narrative codification of its own time and culture. To approach Jesus' death more closely the narrator(s) used poetic language. Words on words on words. Thus the passion and death of Jesus has become literature.

Where does that leave us?

Passion stories try to achieve the impossible. A person's body is at

- See also Od Sol 28; 31; Mekilta, Shirata III, 76; Pirqe Abot de R Natan 44(end); Test Sol 6: 8; and esp Midrash Tehillim (Ps 22) which makes a connection between Ps 22 and the Esther narrative. These texts are not discussed because it cannot be proved that they are written in the time of the writing of the Gospels of Mark or Matthew. Because of the complicated relationship between Jos As and Esther (and Ps 22), I am of the opinion that the interpretation of Esther with the help of Ps 22 can be dated much earlier than the date of edition of this Midrash would suggest. 
stake where there is suffering. More so when the suffering is caused by human violence and superior force. The body is struck in the most literal sense of the word: ridiculed, spat upon, slapped, abused, disfigured, torn apart. The body as something which can be handled and manipulated as can all other things in this world; the body as flesh and blood which trembles and beats and reacts for foreign objects; the body of the other which is not one's own. How can someone else's suffering touch us?

We have to go back to the factual sufferings of people; back to factual tortures where concrete people take a human being and bind him, hit him, trample him, pull and jerk him, destroy him; where people see the fear and the tears, hear the cry and the groaning, notice the body's reaction: how it writhes from the pain, in a reflex of defense, in the final impotence at the very last. In concrete histories of suffering language is unimportant. It is body to body, and the only one who speaks is the brute. Body language is inexpressible but not unintelligible: a cry of horror, the wetting of one's clothes, the vomit of fear; suffering as an experience of limits: the transition from movements to reflex, from mimicry to a sneer, from words to sounds; the opposite from what happens when man is growing from child into adulthood; the suffering of men as part and parcel of the history of mankind, a burden, a scandal, an indictment.

The passion stories speak about this reality. At a time and in a place which do not coincide with where 'it' happened; speaking of people who are no longer or who cannot be identified with the narrator; about the victims who are no more or can no longer speak for themselves; or who, in case they do tell their own story, must speak about those responsible: the executioners, the soldiers, the politicians, the powerful. The moment a story is told, the bodies disappear into thin air of words which call forth other words, in sentences which point to other sentences. To tell a story means that one entrusts a narrative to words and sentences which are at hand: one's own body and/or the body of another in the form of a text.

We must look then to see whether the text has signs of maltreatment: sounds which are unintelligible, sentences which are illogical, a form of behaviour which is beyond explanation - a whole cohort called together, clothes which are put on and taken off, Simon of Cyrene who really has no place at all, passers-by who know everything, night in the middle of the day, a silent Jesus who cries out in Aramaic, a spirit that upsets the netherworld, a centurion who gives meaning to events, 
women who have never been mentioned and who, nevertheless, have been with Jesus since Galilee. The passion narrative in Matthew is not one woven piece but rather a collection of loose threads: scene after scene without an author as its father, unconnected, from the perspective of a narrator who knows everything and understands nothing. Simply telling what one has heard because there has been injustice done.

Against the background of the Greek Septuagint and the Aramaic text in the Targum, parallel to what the hymnist of Qumran tries to do and the narrator of the story about Aseneth, based on the narrative as we find it in Mark, Matthew, as narrator, took Psalm 22, a text which could serve him as anchor for his story. The Psalm lies as a veil over the narrative, even more than in the text of Mark. It is the thread which gives unity to the narrative: Golgotha as a burial place, the soldiers as greedy dogs, the mockers on every side, the total confusion of the persecuted one which brings him to a feeling of being abandoned by God. The words of Psalm 22 bring the narrative together in some sort of unity: what David described, happens in the life and death of Jesus.

If Psalm 22 had no reference to reality this would be literature in the worse sense of the word. Bultmann starts from that supposition as is well known. According to Bultmann (1957/6: 303) Psalm 22 is a literary motive to 'give form to the myth of the passion story'. The problem of the passion of the Messiah must be solved. The authors of the New Testament, therefore, searched for 'prophecies as proof'. Mark and Matthew found them inter alia in Psalm 22. Because David foresaw what would happen to Jesus, the scandal of the passion of Jesus is less schocking: his suffering is part of God's plan. The use of the Psalm is a literary device which is determined by conflict psychology.

That sounds very logical indeed. I ask myself whether the original readers and the narrator of Matthew's gospel would have recognised themselves in this theory. The more intensive use of Psalm 22 in Matthew's text causes an intensification of the factual suffering. In a sense we can say that it has become even more absurd and repellent. The narrative is now about a 'son of God' who hangs on the cross in a burial place and who has been stripped by pagan dogs and is being oggled by them. This more extensive use of the Psalm makes it even more difficult to 'explain' the suffering of the Messiah. If the use of Psalm 22 is intended as proof by prophecy, the least we can say is that the narrator of Matthew's gospel has not been very successful.

Add to this that the parallel texts and parallel interpretations in the Septuagint and the Targum do not know a thing about a messianic or 
prophetic interpretation*. Time and again they use Psalm 22 to find words for the suffering of someone else, that is one saw the Psalm - not exclusively but pre-eminently - as a verbalization of real suffering. As a verbal enunciation the use of the Psalm points to the impotence of one's own words but also to the power of the words of Psalm 22: a last possibility of language to give expression in words to the absurdness of the suffering of someone persecuted.

Probably Matthew wanted to give this to his readers in his reinterpretation of the passion narrative: the suffering of Jesus is like the suffering which the persecuted one in Psalm 22 has to undergo. Jesus entered into this absurd reality of mankind's history.

\section{Works cited}

ABRAHAMS, I 1967/2. Studies in Pharisaism and the Gospels. New York.

BOCK, DL 1987. Proclamatory from prophecy and pattern: Lucan Old Testament Christology. Sheffield.

BULTMANN, R 1964/6. Geschichte der synoptischen Tradition. Göttingen.

BURCHARD, C 1983. Markus 15, 34, ZNW 74, 1-11.

BURCHARD, C 1965. Untersuchungen zu Joseph und Aseneth. Tübingen.

DOMKOWSKY HOPKINS, D 1981. The Qumran Community and $1 \mathrm{Q}$ Hodayot: A reassessment. Revue de Qumran 10.

FRANKEMÖLLE, H 1983. Biblische Handlungsanweisungen. Mainz.

GESE, H 1981. Psalm 22 und das Neue Testament. ZThK 65, 1-22.

GUNDRY, RH 1967. The use of the Old Testament in St Matthew's gospel. Leiden.

DE JONGE, M 1985. Two interpretations of the rending of the Temple-veil in the Testament of the Twelve Patiarchs. Bijdr 46, 349-361.

DE JONGE, M 1986. Matthew 27: 51 in early Christian exegesis. HRT 79, 67-79.

KINGSBURY, JD 1975. Matthew, Structure, Christology, Kingdom. Philadelphia.

KINGSBURY, JD 1986. Matthew as story. Philadelphia.

KODJAK, A 1986. A structural analysis of the Sermon on the Mount. Berlin.

KÖHLER, W-D 1987. Die Rezeption des Matthäus-Evangeliums in der Zeit vor Irenäus.

Tübingen.

- Contrary to this see the Midrash on Ps 22 which gives a 'prophetical' interpretation of the Psalm. Bock's (1987: 146f) fine study demonstrates the difficulty to determine the hermeneutical use of Ps 22 in the passion narrative (i $c$ in Luke's): ' . . there is no fulfilment formula, which is such a crucial one in the view of the church; ... it could be illustrative ...; it could be typological ...; it could be prophetic ...; again the best category in which to describe the allusions' use is typological-prophetic. Jesus suffers in the pattern of an innocent saint and specifically fulfils the plan of God as the innocent sufferer.' Regarding Matthew, I will rather say that Jesus suffers in the pattern of the innocent sufferer (without stressing the definite article). The Psalm is typologically used in the text of Matthew but one should realise that the text of the Psalm itself is as typological as its use in Matthew (or in Mk/Lk). Considering the use of Ps 22 in contemporary texts, Bock's statement on the uniqueness and the completeness of the fulfilment in Jesus (Bock 1987: 341, note 225) should be cancelled. 
LAMARCHE, P 1974. La mort du Christ et le voile du temple. Nouvelle Revue Théol 106, 582-599.

MEIER, JP 1979. The vision of Matthew. New York.

PHILENENKO, M 1968. Joseph et Asèneth. Leiden.

SENIOR, D 1975. The passion narrative according to Matthew. Leuven.

SENIOR, D 1985. The passion of Jesus in the Gospel of Matthew. Delaware.

STRACK, H \& BILLERBECK, P 1965/4. Kommentar zum Neuen Testament aus Talmud und Midrasch. München.

THORION, Y 1983. Der Vergleich in $1 \mathrm{Q}$ Hodayot. Revue de Qumran 11. 